\title{
Development of large diameter plasma sources for semiconductor processes
}

\author{
半導体プロセス用大口径プラズマ源の開発
}

\author{
Haruo SHINDO \\ Department of Applied Physics, School of Engineering, Tokai University, \\ Kitakaname 1117, Hiratsuka 259-1292, JAPAN \\ TEL:+81-463-58-1211,FAX+81-463-58-9461,E-mail:hshindo@keyaki.cc.u-tokai.ac.jp \\ ( Received 1, December 1999 Accepted 28, April 2000)
}

\begin{abstract}
For ultralarge-scale integrated(ULSI) circuit processes, two types of large-diameter plasma generation methods were studied. The one is a microwave plasma by employing a high-permittivity material window. The plasma was produced by the surface-wave and thus the density enhancement was observed with the high permittivity of the dielectric window material. The method was emphasized to be promising in producing a large-diameter plasma for ULSI processes, in particular for photo-resis! ashing. Another source is an RF plasma by employing a multimode antenna. A newly designed antenna with several loops and different modes enabled a large-diameter plasma production having a function of electron energy control. The electron energy was reduced by changing the azimuthal mode of antenna from $m=0$ to $m=2$ with no notable change in electron density. Thus it was concluded that the characteristic length for induction field reverse was essential in conjunction with electron free path.
\end{abstract}

KEYWORDS: large-diameter plasma, surface-wave plasma, inductively coupled plasma, highdensity plasma, resist ashing, ULSI plasma processes

\section{INTRODUCTION}

集積回路(LSI)プロセスにおけるウエハ径の 12 イ ンチ化および最小加工寸法の 0.1 ミクロン化は目前に 迫り、各プロセスの技術的対応が急務となっている。中 でも、プロセスにプラズマを利用するエッチング、 C V D、アッシング等のプロセスでは、微細加工用の大口径 高密度プラズマ源の開発が強く望まれている。

次世代プラズマプロセス技術の研究課題をその重要性 の順に述べると（1）プロセス装置の大口径化、（2） プロセス速度の高速化、（3）プロセスウインドウの拡 幅化である。本研究では、これらの研究課題を抜本的に 解決することを目的として、次世代の新しい高密度プロ セスプラズマ源の開発を目標とする。具体的に上記

（1）および（2）の研究課題については新プラズマ発 生方式の導入が必要で、特に高周波プラズマでは電力導 入用のアンテナ形状が問題となる。また、（3）研究課 題についてはプラズマ電子のエネルギー制御の技術に帰
着する。このような研究課題に対して本研究は次の $2 つ$ の方式による大口径プラズマ源の開発とそのプロセス応 用について実験研究を行ったものである。(1)高誘電率誘 電体導入空による大口径表面波プラズマの生成とレジス トアッシング技術の開発。1,2 (2)マルチモードアンテナ による大口径 $\mathrm{R} F$ プラズマの生成と $\mathrm{SiO} 2 / \mathrm{Si}$ 選択エッチ ング技術。3これら 2 方式によるプロセスプラズマにつ いて結果を述べる。

II. MICROWAVE PLASMA PRODUCED BY EMPLOYING HIGH PERMITTIVITY WINDOW.

A. Experimental apparatus and method

Figure 1には本研究で用いたマイクロ波プラズマ実験 装置図を示す。2.45 G H z のマイクロ波を T E 1 0ーTM0 1 モード変換器を通して導入し、直径2 40 фのアルミ容器内にプラズマを生成した。プラズマ容器 のマイクロ波導入部には次の 3 種類の方法を用い、プラ 
ズマ特性の違いを比較した。（1）13mm厚石英円板、 (2) $7 \mathrm{~mm}$ 厚石英円板、（3） $7 \mathrm{~mm}$ 厚アルミナ円板。 ここで 2 種類厚の石英円板を用いた理由は、誘電体空の 誘電率の影響を調べる上で厚さを揃える必要があり、そ のため $7 \mathrm{~mm}$ 厚石英円板およびアルミナ円板を用意した が、石英は強度的に弱く、通常の実験は $13 \mathrm{~mm}$ 厚石英円 板を用いる必要があるためである。本実験で用いた石英 円板とアルミナ円板の電気的特性は、石英の場合で誘電 率がどちらの場合とも3.8程度であり、アルミナの場合 で9.7と誘電率は 3 倍近くも大きい。生成したプラズマ の診断は直径 1-0.5申の白金製平面ラングミュアープ ローブを用いて行った。なお、本実験における位置の基 準は図 1 に示すように、軸方向 Z については石英および アルミナ円板の下面であり、半径方向については中心軸 である。以後、測定值はすべてこの座標系で示される。

また、1 $1 \mu \mathrm{m}$ 厚で $\mathrm{i}$ 線用レジストを塗布したシリコン 基板を加熱銅電極上に設置し、各プラズマ条件に対する レジストアッシング速度を調べた。基板温度は 200 $300{ }^{\circ} \mathrm{C}$ である。なお、基板の電気的条件は浮遊電位で ある。

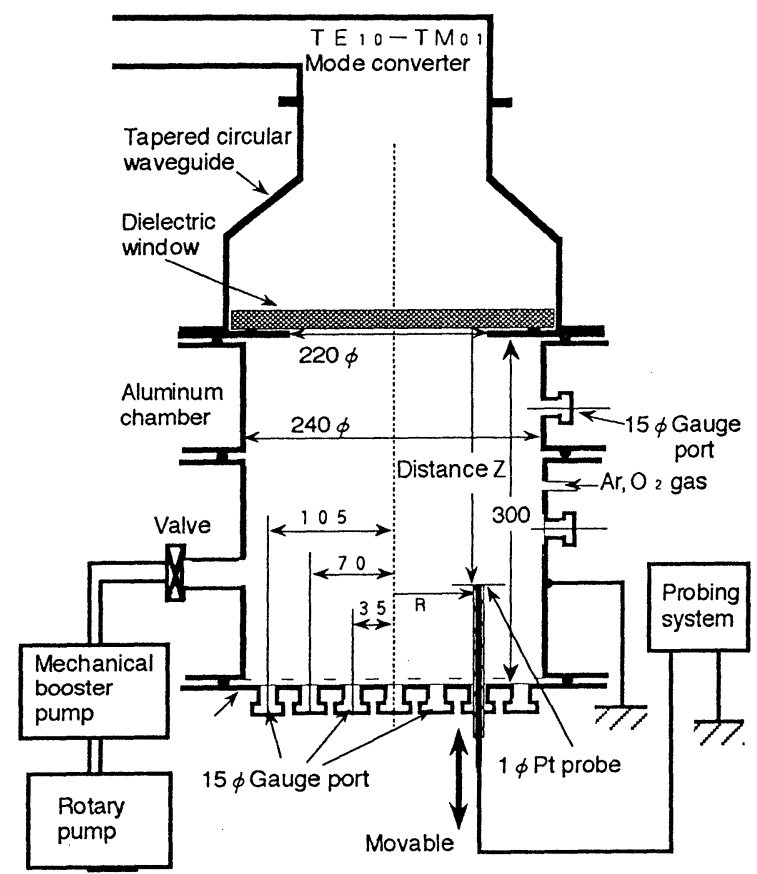

FIG.1 Experimental apparatus.

B. Experimental result and discussion

1. Microwave power dependences

Figure 2 には圧力0.1Torrの酸素プラズマにおいて得ら れた電子密度のマイクロ波電力依存性を示した。測定の 軸方向位置は $Z=5.8 \mathrm{~cm}$ である。マイクロ波導入部形状 としてはアルミナ板 $(7 \mathrm{~mm}) 、 7 \mathrm{~mm}$ おび $13 \mathrm{~mm}$ 厚石英板 の 3 種類である。マイクロ波電力の增加とともに電子密 度はどの条件においても増加するが、その依存性はマイ
クロ波導入部により大きく異なる。特にアルミナの場合 にはその依存性は強く、マイクロ波電力 $1 \mathrm{~kW}$ にいいて $6 \times 10^{11}\left(\mathrm{~cm}^{-3}\right)$ 程度で、これは同一厚さの石英と比較して2 倍もの高密度になっている。このようなアルミナの場合 における電子密度の強いマイクロ波電力依存性にはアル ゴンの場合と同様にアルミナの高誘電率および低誘電体 損の特性か関係しており、表面波によるプラズマ生成の 特徴であることが後で示される。更に、アルミナの場合 におけるマイクロ波電力依存性において低電力領域では 不連続な変化が見られる。このような低電子密度領域に おける異常な変化には表面波の発生限界が関係してい る。これについては後述する。一方、電子温度の測定值 ではアルミナの場合の特に低マイクロ波電力の領域で極 端に高くなる傾向が見られた。この極端な変化は電子密 度の場合の不連続的変化に対応したもので、この原因と しては表面波の発生限界が関係している。また、その他 の導入法においては電子温度の電力依存性は弱いが低電 力の領域で電子温度が高くなるようなアルミナと同様の 傾向が僅かに見られた。

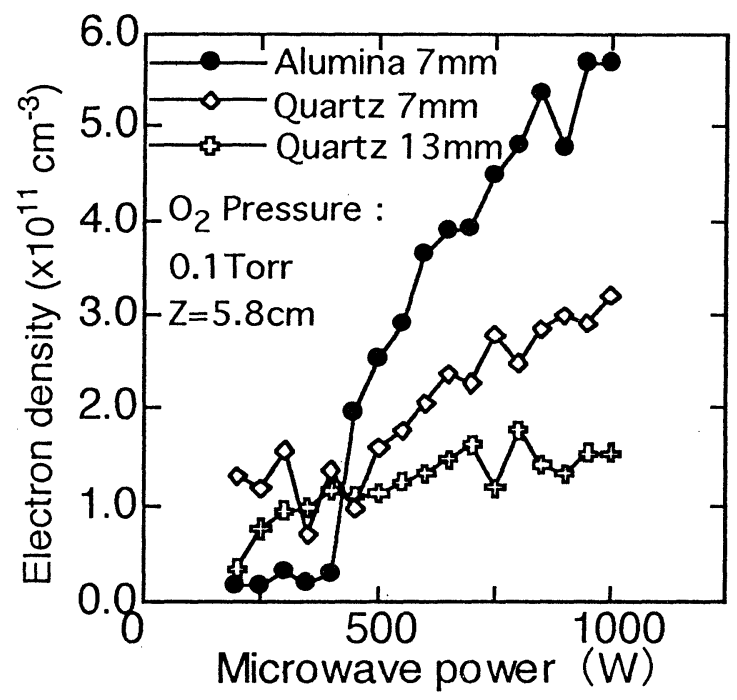

FIG.2 Power dependences of electron density.

\section{Axial distributions of parameters.}

Figure 3 においては、圧力0.1Torrにおける電子密度お よび電子温度の軸方向依存性を 3 種の導入法について比 ベたものである。いずれの導入法でも電子密度はマイク 口波導入部へ近ずくに従って増加し、アルミナの場合に は $10^{12}\left(\mathrm{~cm}^{-3}\right)$ にもな。一方、電子温度では導入法によ る大きな差は見られなかった。アルミナの場合の電子密 度変化を石英円板と比べると、圧力が0.1Torrのときアル ミナでの密度は下流域まで石英円板を上回るが、これは マイクロ波モード観察の結果、表面波モードが（1、 0)のように中心部に集中しているためであことが明ら かとなった。これに対し、石英円板では軸方向分布が平 
坦になるような傾向にあり、明らかに表面波モードから はずれる傾向にある。

\section{Microwave dispersion and plasma parameters.}

実験結果で示したように、酸素プラズマのマイクロ波 電力依存性および圧力依存性よりアルミナを導入部とし た場合のプラズマ電子密度は大きく増加し、マイクロ波 カットオフ密度 $7.4 \times 10^{10}\left(\mathrm{~cm}^{-3}\right)$ 以上になることがわかっ た。これらの結果より、マイクロ波導入部誘電体とプラ ズマ界面を伝搬する表面波が関与していることが考えら れる。プラズマ密度が増加し、マイクロ波周波数のカッ トオフ密度以上になるとマイクロ波はプラズマボリュー 厶内に進入できず、誘電体とプラズマの界面に局在する ようになり、これが表面波モードを作り出す。誘電体境 界では電束密度が連続であり、その結果プラズマ誘電率 が誘電体のそれと等しくなるように、高誘電率の場合に 泣プラズマ密度が増加しなければならない。これが本実 験においてアルミナ空で高密度を発生するメカニズムで あり、この高密度プラズマが界面付近に局在するのが特 徵となる。

\section{Resist ashing characteristics}

Figure 4 には圧力1Torrにおいて得られたレジストの アッシング速度をアルミナおよび石英の場合について比 較して示した。

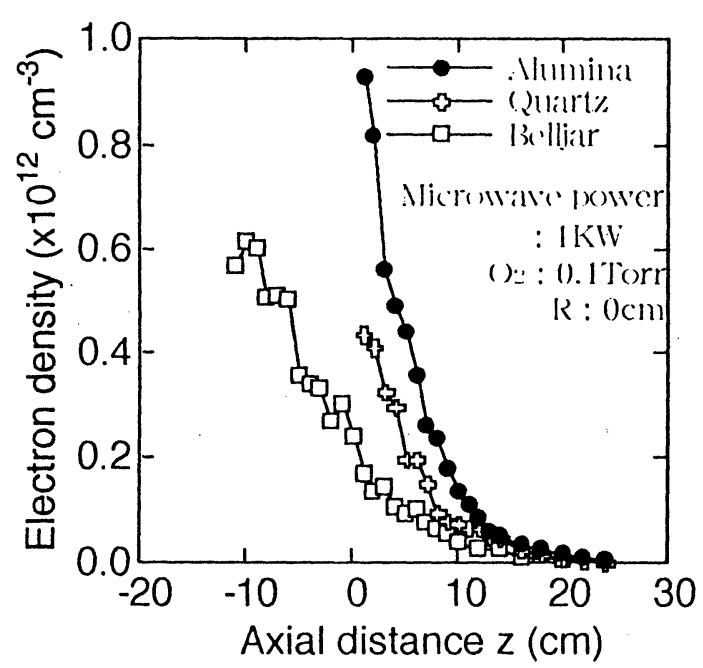

FIG.3 Axial variations of electron density.

III. HIGH DENSITY RF PLASMA PRODUCED BY EMPLOYING MULTI-MODE ANTENNA.

低圧高密度プラズマによるUＬＳＩエッチングでは、 高選択性の確保や形状異常の防止等の観点よりプラズマ 電子のエネルギー制御が強く望まれている。例えば、 $\mathrm{SiO} / \mathrm{Si}$ 選択エッチングでは、垂直形状を確保するため

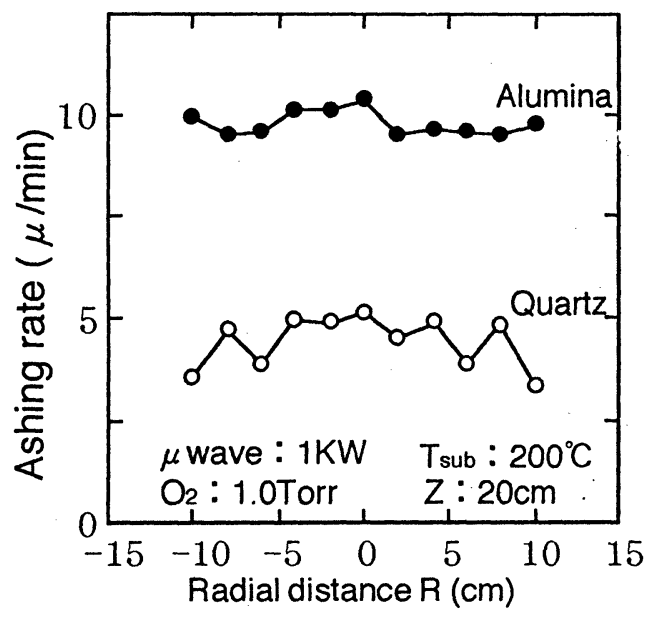

FIG.4 Comparison of resist ashing rates.

に、出来るだけ低圧条件でエッチングを行う必要がある が、低圧条件で高密度プラズマを生成すると、電子エネ ルギーが過度に上昇し、ラジカルが過度に分解され、選 択性が確保出来なくなる等の問題が発生している。誘導 結合型プラズマ（ＩＣＰ）において生成用アンテナの方 位角方向モードを変えることにより誘導電界の反転領域 が変わるが、本実験では、この反転領域の寸法を変える ことにより電子エネルギーの制御を試みた。

\section{A. Experimental apparatus and method}

Figure 5 に示すように、14インチS USチャンバー内 に石英窓を介して銅板製一巻きアンテナにより $13.56 \mathrm{M}$ H z R F電力を供給し、アルゴンプラズマを生成した。 アンテナの方位角方向モードmを変え、生成されるプラ ズマの電子エネルギーおよび電子密度の相違を主に調べ た。アンテナの方位角方向モードは図中に示すように、 R F 電力のフィーダ点を変えることにより、変化させ た。生成したアルゴンプラズマはラングミュアープロー ブおよび発光分光分析法により診断を行った。発光分光 分析は軸方向位置 $z=9.5 \mathrm{~cm}$ の位置で横方向よりレ ンズおよびファイバーを組み合わせて原子線およびイオ ン線の強度測定を行った。

B. Experimental result and discussion

1. RF power dependences

Figure 6 にはモード数 $\mathrm{m}=0$ および 1 において圧力 1 mTorrで得られた電子密度、温度の R F 電力依存性を示 した。電子温度は予測の通り $\mathrm{m}=1$ モードで $50 \%$ 程度 $\mathrm{m}$ $=0$ の場合より低く、この傾向はR $\mathrm{F}$ 電力により大きな 変化は見られない。一方、電子密度は R F 電力 $1 、 5 \mathrm{k}$ $\mathrm{W}$ 境に逆転し、高電力領域では $\mathrm{m}=1$ モードが高密度 となる。このような密度の逆転はアンテナ直径が大きく なると高電力側に移動した。Figure 7 には同一条件で得 られたArI及びArII線スペクトルの $\mathrm{m}=1$ に対する $\mathrm{m}=$ 


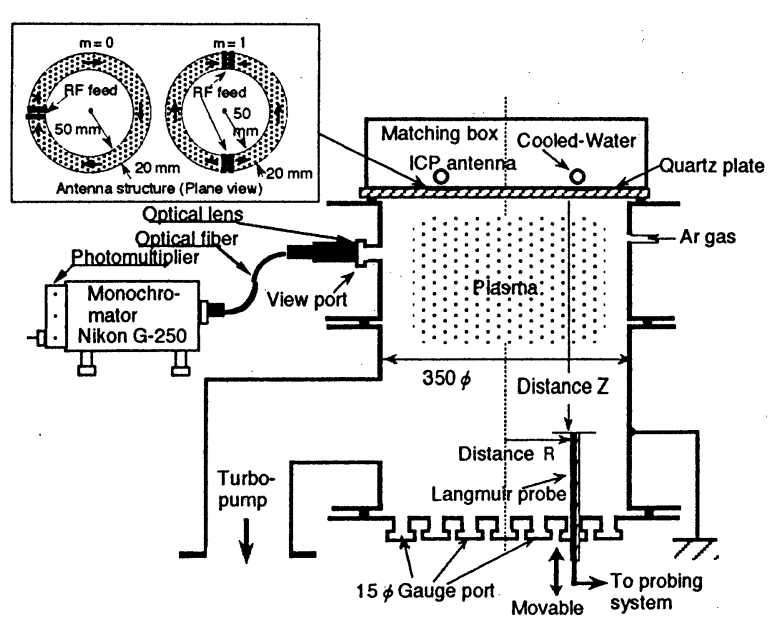

FIG.5 Experimental apparatus.

0 の強度比を示した。発光強度の変化はFigure 6 のプ ローブ測定による結果を良く説明している。発光分光分 析ではさらに他のArI及びArII線強度も測定したがFigure 7 とほぼ同様の結果であった。Figures 6、7の結果はア ンテナモード数を変えることにより高電子密度で低電子 温度のプラズマが実現出来ることを示している。アン テナの方位角方向モードが增えると、誘導電界による 電子の加速距離が減少し、この距離よりも電子の平均 自由行程が長い場合には、電子は加速と同時に減速の 効果を受けるようになり、電子エネルギーの低減化が 起こると考えられる。これらの結果は低圧高密度プラ ズマによるUL S I エッチングにおいて極めて重要で あり、実際のエッチングにおいて高選択性の確保や形 状異常の防止等が可能になると考えられる。

\section{ACKNOWLEDGMENTS}

本研究の一部は東海大学におけるレインボー2 1 プ ロジェクト研究として行われたものであり、ここに記 して謝意を表します。

\section{REFERENCES}

${ }^{1}$ M.Furukawa, N.Saito, K.Kawamura, and H.Shindo, Jpn. J. Appl. Phys., 37(8B),pp.L1005-L1007(1998).

${ }^{2}$ M.Furukawa, K.Shinagawa, K. Kawamura and H. Shindo, Jpn. J. A.ppl. Phys., 38((8), PP.4905-4909 (1999).

${ }^{3}$ H. Shindo, T.Urayama, T. Fujii, Y. Horiike and S.Fujii, Jpn. J. Appl. Phys., 38((9AB), PP.L1066-L1069 (1999).

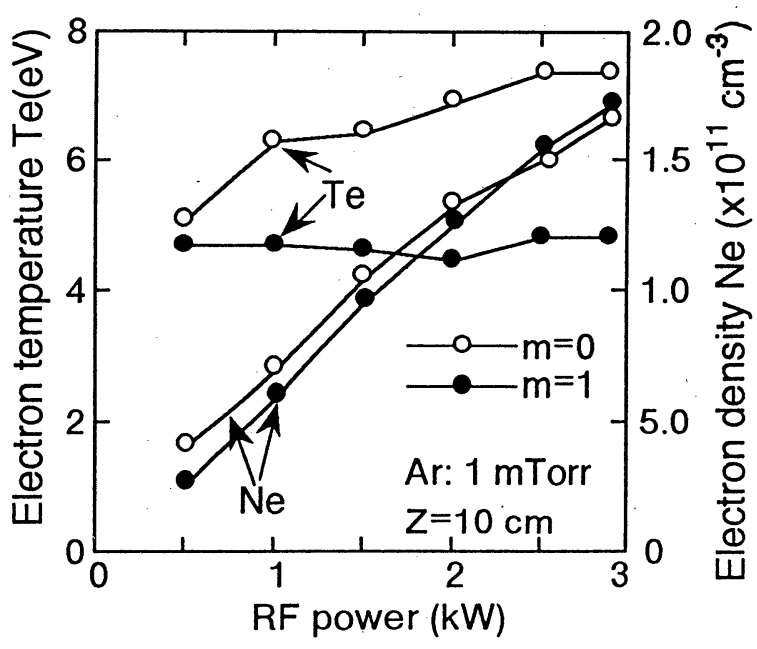

FIG.6 Power dependences of $\mathrm{Ne}$ and $\mathrm{Te}$.

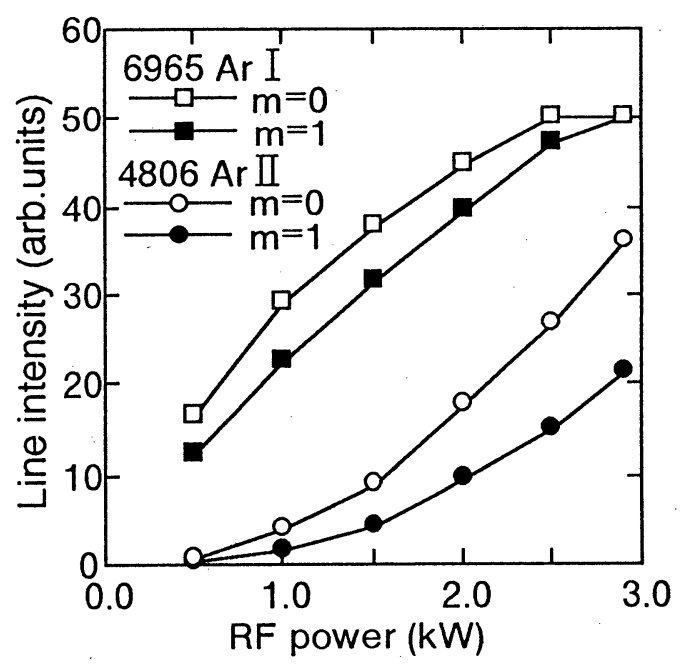

FIG.7 Power dependences of line intensities.

進藤 春雄 (しんどうはるお)

昭和 22 年 2 月 20 日生

昭和 46 年 3 月 秋田大学大学院修士課程修了

昭和 46 年 4 月 広島大学助手

平成 4 年 4 月 福山大学助教授

平成 7 年 10 月 東海大学応用物理学科教授

現在に至る。

この間、ブラズマ物理および応用に関する研究に従事。 